\title{
Antifungal activity and mode of action of thymol and its synergism with nystatin against Candida species involved with infections in the oral cavity: an in vitro study
}

\author{
Ricardo Dias de Castro ${ }^{1 *}$, Trícia Murielly Pereira Andrade de Souza², Louise Morais Dornelas Bezerra², \\ Gabriela Lacet Silva Ferreira ${ }^{1}$, Edja Maria Melo de Brito Costa $^{3}$ and Alessandro Leite Cavalcanti ${ }^{3}$
}

\begin{abstract}
Background: Limitations of antifungal agents used in the treatment of oral candidiasis, as the development of resistant strains, are known by the scientific community. In this context, the aim of this study was to evaluate the antifungal activity of thymol against Candida albicans, Candida tropicalis and Candida krusei strains and to determine its mode of action and synergistic effect when combined with the synthetic antifungal nystatin.

Methods: The minimum inhibitory concentration (MIC) was determined using a microdilution technique, and the minimum fungicidal concentration (MFC) was determined via subculture sowing. The mode of action of thymol was established by verifying fungal growth in the presence of sorbitol or ergosterol. The fractional inhibitory concentration index (FIC) was determined using the checkerboard method.

Results: Thymol presented an antifungal effect, with MICs of $39 \mu \mathrm{g} / \mathrm{mL}$ for C. albicans and C. krusei and $78 \mu \mathrm{g} / \mathrm{mL}$ for $C$. tropicalis. The results of the antifungal test remained unchanged in the presence of sorbitol; however, the MIC value of thymol against C. albicans increased eight times (from 39.0 to $312.5 \mu \mathrm{g} / \mathrm{mL}$ ) in presence of exogenous ergosterol. The combination of thymol and nystatin reduced the MIC values of both products by $87.4 \%$, generating an FIC index of 0.25 .
\end{abstract}

Conclusions: Thymol was found to have a fungicidal effect on Candida species and a synergistic effect when combined with nystatin.

Keywords: Microbiology, Candida albicans, Thymol

\section{Background}

The emergence of opportunistic fungal infections, especially in immunocompromised individuals, highlights the need to elucidate new therapeutic options, especially because the microorganisms involved usually have remarkable morphological plasticity and express genes involved in the mechanisms of resistance to antifungal agents [1].

\footnotetext{
* Correspondence: ricardodiasdecastro@yahoo.com.br

'Postgraduate Program in Dentistry, School of Dentistry, Universidade Federal da Paraíba, Campus I, ZIP: 58.051-900 Joao Pessoa, Paraiba, Brazil Full list of author information is available at the end of the article
}

Oral candidiasis is a superficial infection that affects the palate region and jugal mucosa. It is notable for its high prevalence and the limited therapeutic tools available for treatment. It is an infection produced by microorganisms of the genus Candida; Candida albicans is the most common and most pathogenic species [2-4], although Candida tropicalis and Candida krusei have important roles in the development of the disease [5, 6].

Local and systemic factors may predispose individuals or trigger clinical cases of oral candidiasis. Such factors include saliva acidity, hyposalivation, nightly use of dental prostheses, endocrine disorders, nutritional deficiencies,

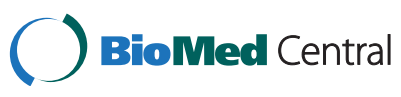

(c) 2015 de Castro et al. Open Access This article is distributed under the terms of the Creative Commons Attribution 4.0 International License (http://creativecommons.org/licenses/by/4.0/), which permits unrestricted use, distribution, and reproduction in any medium, provided you give appropriate credit to the original author(s) and the source, provide a link to the Creative Commons license, and indicate if changes were made. The Creative Commons Public Domain Dedication waiver (http://creativecommons.org/publicdomain/zero/1.0/) applies to the data made available in this article, unless otherwise stated. 
smoking, poor oral hygiene, immunosuppressive drug use and radiotherapy and chemotherapy treatment of maxillofacial structures [7].

The use of nystatin to treat tissue injury has been recommended [8], although other substances, such as miconazole, fluconazole, and ketoconazole may be prescribed instead [9-11]. However, indiscriminate use and the small number of available antifungal agents have promoted the development of resistant strains, especially in immunocompromised individuals [12]. This fact justifies the development of new therapies for use in clinical practice $[13,14]$.

Among these new therapies, natural products stand out; they are considered sources of bioactive molecules with potential therapeutic applications in medicine and dentistry $[15,16]$. Many studies have been conducted on the antifungal activity of natural products against Candida species involved in fungal infections of the oral cavity [17-19]. Natural products include essential oils and their constituents [20,21], which may belong to several classes of compounds, but terpenes and phenylpropenes are the most common [16].

The interest in isolated monoterpenes has grown over the past years as a result of their pharmacological use. This increase in interest is particularly true for thymol, which is a known antimicrobial agent [22, 23]. The use of individual components provides greater predictability, allowing the minimization of adverse effects [24].

Thymol (2-isopropyl-5-methylphenol) is a phytoconstituent classified as a monoterpene [25]. It is the majority phytoconstituent in the essential oil of thyme (Thymus vulgaris) [24] and is a major component of the essential oil of oregano (Origanum vulgare) [16]. Some studies have shown that thymol has antiseptic, antiinflammatory, antioxidant and healing properties and a broad spectrum of biological activity [26-28].

Previous studies have shown that the toxicity of thymol, like that of any other substance, is directly related to the concentration applied to cell cultures [29]. The exposure of human fibroblasts to different concentrations of thymol (25 to $100 \mu \mathrm{g} / \mathrm{mL}$ ) revealed cell viability above $96 \%$ when at 24, 48 and $72 \mathrm{~h}$ [30]. The cytotoxic activity (50\% lethal concentration) of thymol in U-937 human promonocytic cells was $\mathrm{LC}_{50} \geq 400 \mu \mathrm{g} / \mathrm{mL}$ [31].

In this context, the present study investigated the antifungal activity of thymol against $C$. albicans strains with respect to growth inhibition, microbial death, mode of action and synergistic effect in combination with the synthetic antifungal nystatin.

\section{Methods}

Research site

The microbiological tests were performed at the Laboratory of Oral Microbiology, Tropical Medicine Center
(NUMETROP) - Center for Health Sciences, Federal University of Paraiba, Paraiba, Brazil.

\section{Microorganisms}

The reference Candida spp. strains used in this study were Dutch cultures from the Central Bureau voor Schimmel (CBS; Fungi Culture Central Office): C. albicans CBS 562, C. tropicalis CBS 94 and C. krusei CBS 573.

\section{Test products}

The phytoconstituent thymol provided by Quinari ${ }^{\oplus}$ (Ponta Grossa, Parana, Brazil) and the synthetic antifungal nystatin (Sigma-Aldrich, St. Louis, USA) were used in the in vitro assays. The thymol presented as a white powder and was solubilized in $70^{\circ} \mathrm{GL}$ alcohol.

\section{Minimum inhibitory concentration (MIC)}

The MIC was determined using the microdilution technique. Ninety-six-well microtiter plates with a U-shaped bottom were used (ALAMAR ${ }^{\oplus}$, Diadema, São Paulo, Brazil). Initially, $100 \mu \mathrm{L}$ of Sabouraud Dextrose Broth (SDB) (HIMEDIA ${ }^{\oplus}$, Mumbai, India) was distributed in the plate holes. Then, $100 \mu \mathrm{L}$ of thymol solution was transferred to the first well and serially diluted by transferring an aliquot of $100 \mu \mathrm{L}$ from the most concentrated well to the next cavity. Thus, thymol concentrations from $5.000 \mu \mathrm{g} / \mathrm{mL}$ to $2.44 \mu \mathrm{g} / \mathrm{mL}$ were obtained. Finally, $100 \mu \mathrm{L}$ of inoculum corresponding to each strain was added to each cavity [32].

The inocula were prepared in $0.9 \%$ saline, and the turbidity of the fungal suspensions was compared with that of the solution in tube 0.5 of the McFarland nephelometric scale, which corresponds to an inoculum of approximately $10^{6} \mathrm{CFU} / \mathrm{mL}$, and adjusted as needed. Then, the suspension was diluted in SDB to obtain an inoculum concentration of $10^{3} \mathrm{CFU} / \mathrm{mL}$ [32].

Meanwhile, the viability of yeast strains (growth control) and medium sterility were controlled. As a positive control, the synthetic antifungal nystatin was used. Through serial dilution, nystatin concentrations from $1,000 \mu \mathrm{g} / \mathrm{mL}$ to $0.48 \mu \mathrm{g} / \mathrm{mL}$ were obtained. As a negative control, $70^{\circ}$ GL alcohol was diluted in water in the same proportions used for solubilization of thymol.

The test was performed in triplicate, and the microtiter plates were incubated at $35{ }^{\circ} \mathrm{C}$ for $24 \mathrm{~h}$. A visual reading was performed to determine the MIC of thymol on yeast strains. The formation of cell clumps ("buds") on the bottoms of the wells was considered. Thus, the lowest test product concentration that could visibly inhibit fungal growth was considered the MIC [32].

To confirm the presence of viable microorganisms, $10 \mu \mathrm{L}$ of TTC dye (2,3,5-triphenyl tetrazolium chloride) was used. This dye reflects the activity of the dehydrogenase enzymes involved in the process of cell respiration [33]. 


\section{Minimum fungicidal concentration (MFC)}

After the MIC determination, aliquots of the concentration corresponding to the MIC and the two immediately most concentrated concentrations (for the thymoltreated cultures and the positive and negative controls) were subcultured in Petri dishes containing Sabouraud Dextrose Agar (SDA; HIMEDIA', Mumbai, India) and incubated at $35{ }^{\circ} \mathrm{C}$ for $48 \mathrm{~h}$. The MFC was defined as the lowest product concentration that prevented visible growth; that is, the lowest concentration that was able to kill the fungus [32].

The MFC/MIC ratio was calculated to determine whether thymol has a fungistatic $(\mathrm{MFC} / \mathrm{MIC} \geq 4)$ or fungicidal activity $(\mathrm{MFC} / \mathrm{MIC}<4)$ [34].

\section{Mode of action}

The mode of action was tested to indicate whether the antifungal activity of thymol involves a direct interaction with the cell wall structure of $C$. albicans (via testing with sorbitol) or with the ion permeability of the membrane of this organism (via the test with ergosterol).

\section{Test with sorbitol}

The MIC of thymol in the presence sorbitol (an osmotic protector) against $C$. albicans was determined using the microdilution technique [32] in triplicate.

Initially, $100 \mu \mathrm{L}$ of SDB was added to each well of the microtiter plate. Subsequently, $100 \mu \mathrm{L}$ of thymol solution was transferred to the first well and serially diluted with the removal of an aliquot of $100 \mu \mathrm{L}$ from the most concentrated well to the subsequent cavity. Thymol solution concentrations from $5.000 \mu \mathrm{g} / \mathrm{mL}$ to $2.44 \mu \mathrm{g} / \mathrm{mL}$ were obtained. Then, $100 \mu \mathrm{L}$ of fungal inoculum $\left(10^{3} \mathrm{CFU} / \mathrm{mL}\right)$ prepared in SDB previously supplemented with sorbitol (Sigma-Aldrich, St. Louis, USA) was transferred to the wells for a final concentration of $0.8 \mathrm{M}$ sorbitol in each well [35-37].

A microorganism control was created by placing $100 \mu \mathrm{g}$ of SDB and $100 \mu \mathrm{g}$ of the inoculum with sorbitol $(0.8 \mathrm{M})$ in each cavity. Sterility control was also performed; $100 \mu \mathrm{g}$ SDB with sorbitol $(0.8 \mathrm{M})$ was placed in a plate column without fungal suspension. The plates were incubated at $35{ }^{\circ} \mathrm{C}$ and the results were read after $48 \mathrm{~h}$ and again after 7 days [35-37].

\section{Test with ergosterol}

To determine whether thymol interacts with ergosterol, the MIC against C. albicans was determined using the microdilution technique [32] in triplicate in the presence and absence of exogenous ergosterol (Sigma-Aldrich, St. Louis, USA).

First, $100 \mu \mathrm{L}$ of SDB was added to each well of the microtiter plate. Then, $100 \mu \mathrm{L}$ of thymol solution was transferred to the first well and serially diluted by transferring a
$100 \mu \mathrm{L}$ aliquot from the most concentrated well to the next well. Thymol solution concentrations from 5.000 to $2.44 \mu \mathrm{g} / \mathrm{mL}$ were obtained. Subsequently, $100 \mu \mathrm{L}$ of fungal inoculum $\left(10^{3} \mathrm{CFU} / \mathrm{mL}\right)$ prepared in SDB previously supplemented with ergosterol in concentrations of 100 , 200 and $400 \mu \mathrm{g} / \mathrm{mL}$ was transferred to the wells [35, 37].

Nystatin was tested as a positive control, and yeast growth and sterility were also controlled.

\section{Synergism test: checkerboard method}

The combined effect of the two substances (nystatin and thymol) was determined using the checkerboard technique to derive the fractional inhibitory concentration (FIC) index.

Test product solutions of certain concentrations (determined by their respective MICs) were used. Initially, $100 \mu \mathrm{L}$ of SDB was added to the wells. Then, $50 \mu \mathrm{L}$ of each test product at various concentrations (MIC x 8 , MIC x 4 , MIC x 2 , MIC, MIC $\div 2$, MIC $\div 4$, and MIC $\div 8$ ) was added horizontally (thymol) and vertically (nystatin). Finally, $10 \mu \mathrm{L}$ of fungal inoculum of the tested strains was added $\left(10^{3} \mathrm{CFU} / \mathrm{mL}\right)$. Growth and sterility controls were also performed. The results were read visually, and fungal growth was shown using TTC dye. The assay was performed in triplicate, and the microplate was incubated for $48 \mathrm{~h}$ at $35^{\circ} \mathrm{C}[38-40]$.

The FIC index was calculated as the sum of FIC $^{\mathrm{A}}+$ $\mathrm{FIC}^{\mathrm{B}}$, where $\mathrm{A}$ is thymol and $\mathrm{B}$ is nystatin. $\mathrm{FIC}^{\mathrm{A}}$, in turn, is calculated using the $\mathrm{MIC}^{\mathrm{A}}$ combined/MIC ${ }^{\mathrm{A}}$ alone ratio, while $\mathrm{FIC}^{\mathrm{B}}=$ the $\mathrm{MIC}^{\mathrm{B}}$ combined $/ \mathrm{MIC}^{\mathrm{B}}$ alone ratio. This index was interpreted as follows: synergism $(<0.5)$, additivity $(0.5-1.0)$, indifference $(>1)$ or antagonism (>4.0).

\section{Results}

\section{MIC and MFC determination}

The MIC and MFC values of thymol and nystatin against Candida spp. are shown in Table 1. The vehicle

Table 1 Antifungal activity of thymol against Candida spp

\begin{tabular}{|c|c|c|c|c|c|c|}
\hline \multirow[t]{3}{*}{ Strain } & \multicolumn{3}{|l|}{ Thymol } & \multicolumn{3}{|l|}{ Nystatin } \\
\hline & MIC & MFC & MIC/MFC & MIC & MFC & $\mathrm{MIC} / \mathrm{MFC}$ \\
\hline & $(\mu \mathrm{g} / \mathrm{mL})$ & $(\mu \mathrm{g} / \mathrm{mL})$ & ratio & $(\mu \mathrm{g} / \mathrm{mL})$ & $(\mu \mathrm{g} / \mathrm{mL})$ & ratio \\
\hline $\begin{array}{l}\text { Candida } \\
\text { albicans }\end{array}$ & 39.0 & 39.0 & 1 & 1.9 & 1.9 & 1 \\
\hline \multicolumn{7}{|l|}{ CBS 562} \\
\hline $\begin{array}{l}\text { Candida } \\
\text { tropicalis }\end{array}$ & 78.0 & 78.0 & 1 & 1.9 & 1.9 & 1 \\
\hline \multicolumn{7}{|l|}{ CBS 94} \\
\hline $\begin{array}{l}\text { Candida } \\
\text { krusei }\end{array}$ & 39.0 & 39.0 & 1 & 1.9 & 1.9 & 1 \\
\hline CBS 573 & & & & & & \\
\hline
\end{tabular}

Notes: MIC Minimum inhibitory concentration, MFC Minimum fungicidal concentration 
used in the thymol solution $\left(70^{\circ} \mathrm{GL}\right.$ alcohol), at the same concentration found in the solution of lower concentration of thymol which promoted fungal growth inhibition, was not effective, meaning that it did not interfere with the MIC values of the tested product against yeasts. The MIC/MFC ratio for thymol showed that it had a fungicidal effect against all of the tested strains.

\section{Mode of action of thymol}

The results showed that the antifungal properties of thymol are not related to the biosynthetic pathways of the cell wall because the results of the antifungal test remained unchanged in the presence of an osmotic protector (MIC in presence of sorbitol: $39.0 \mu \mathrm{g} / \mathrm{mL}$ ). In contrast, the MIC value of thymol against $C$. albicans increased eight times (39.0 to $312.5 \mu \mathrm{g} / \mathrm{mL}$ ) in the presence of exogenous ergosterol (Fig. 1), which indicates that thymol appears to bind to the ergosterol in the membrane, which increases ion permeability and ultimately results in cell death. The same mode of action was also observed for synthetic antifungal nystatin, which was used as a positive control.

\section{Synergism test}

As a result of combining thymol with nystatin, a significant reduction in the MIC values was observed. For both products, the MIC reduction was $87.4 \%$ for the three Candida strains tested. The FIC index value was 0.25 , indicating a synergistic effect $(\mathrm{FIC}<0.5)$ for this association in relation to the growth inhibition of the tested strains (Table 2).

\section{Discussion}

The high prevalence and severity of infections caused by yeasts of the genus Candida, which can cause significant morbidity and mortality in affected patients (usually hospitalized), has encouraged investigations to elucidate new therapeutic approaches to treat candidiasis [41].

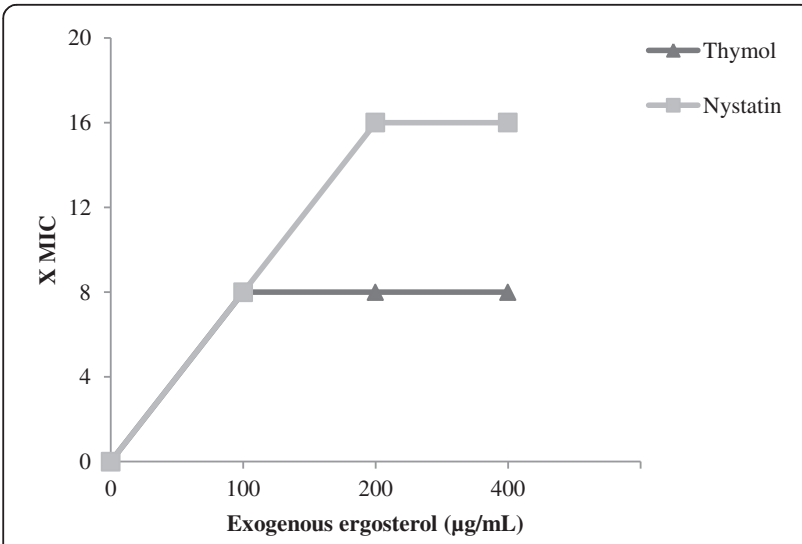

Fig. 1 The effect of different concentrations of exogenous ergosterol (100-400 $\mu \mathrm{g} / \mathrm{mL}$ ) on the MIC (minimum inhibitory concentration) of thymol and nystatin against Candida albicans
Table 2 The MIC of thymol and nystatin, when used in association, and their combined FIC index values

\begin{tabular}{lllll}
\hline Strain & $\begin{array}{l}\text { MIC of thymol } \\
(\mu \mathrm{g} / \mathrm{mL})\end{array}$ & $\begin{array}{l}\mathrm{MIC} \text { of nystatin } \\
(\mu \mathrm{g} / \mathrm{mL})\end{array}$ & $\mathrm{FIC}$ & Interpretation \\
\hline $\begin{array}{l}\text { Candida albicans } \\
\text { CBS 562 }\end{array}$ & 4.88 & 0.24 & 0.25 & Synergism \\
$\begin{array}{l}\text { Candida tropicalis } \\
\text { CBS 94 }\end{array}$ & & & & \\
Candida krusei & 4.88 & 0.24 & 0.25 & Synergism \\
CBS 573 & & 0.24 & 0.25 & Synergism \\
\hline
\end{tabular}

Note: MIC Minimum inhibitory concentration, FIC Fractional inhibitory concentration index

Because the oral cavity includes Candida spp. in its normal microbiota and because this disease is considered an opportunistic infection, is an important site of disease development.

This study used the Candida species usually identified in oral fungal infections. C. albicans is present in the oral cavities of approximately 30 to $50 \%$ of people. It is among the most virulent species [42]; it is able to produce phospholipases and proteases that can destroy host tissues [43], and it expresses genes that are responsible for the cellular responses involved in invasive growth, cell wall formation, adaptation to osmotic stress [4] and resistance to currently available antifungal agents in the form of efflux pumps [44, 45], changes in the drugs' site of action [46], and changes in the lipid composition of the fungal plasma membrane, which prevent the drugs' inflow into the cell [47].

C. tropicalis and C. krusei are also important pathogens that contribute to the development of the disease. Strains that are resistant to available therapeutic agents have begun to appear, and there has been an increasing number of immunocompromised people and increasingly frequent use of antifungal agents for treatment and/or prophylaxis $[48,49]$.

Low thymol concentrations were needed to inhibit the growth of Candida strains, and thymol's fungicidal effect is considered important for infection control because the immune responses of the host are usually compromised, making it difficult for affected patients to recover their health. The anti-Candida effect promoted by thymol has been reported in other studies [50,51]. Previous studies have shown that thymol is able to significantly reduce the number of viable $C$. albicans cells, reducing up to $82 \%$ the biofilm mass formed by this microorganism [52].

The elucidation of the action mechanisms of agents with pharmacological potential, whether of natural or synthetic origin, contributes to the development of rational therapeutic approaches, particularly in terms of infections caused by resistant microorganisms, which frequently require combinations of drugs or the use of 
new drugs when the first-choice agent is not effective. The results of this study suggest that thymol acts at the level of the fungal plasma membrane by interfering with the process of ergosterol biosynthesis, promoting increased membrane permeability and causing the depletion of components essential to fungal cell survival $[23,25]$.

Generally, terpenes, particularly monoterpenes such as thymol, are characterized by the chemical formula $\mathrm{C}_{10} \mathrm{H}_{16}$, which may be cyclic or branched. The chemical configuration of these molecules gives them hydrophobic properties and allows them to deposit on the lipophilic structures of microorganisms such as the plasma membrane; this deposition leads to increased permeability with a consequent loss of the electrolytes essential to cell survival [20]. Other action mechanisms may be involved, such as the inhibition of spore germination, fungal proliferation and cell respiration [53].

Natural products with intrinsic antimicrobial activity or products that promote the activity of commonly used antibiotic/antifungal agents may represent new ways to combat multiresistant microorganisms and prevent the contact of these microorganisms with synthetic products, thus reducing the risk of selecting new or improved resistance mechanisms [54]. Natural products may also be combined with traditional antimicrobials to enhance the antimicrobial activity of both [55].

According to the literature, there are scientific evidences for the use of nystatin in the treatment of fungal infections of the oral mucosa [56] and it has been indicated, with advantages over the other antifungals, such as topical use and less side effects [57]. However, fungal resistance has been reported [57] and the association between synthetic and natural antifungal is an alternative to reducing the dose required for the effect and may reduce undesired side effects and prevent the development of resistance to antifungals [58].

In the laboratory tests performed to investigate the antimicrobial activity of synthetic or natural agents, one of the simplest and best known protocols is the checkerboard test, which provides a two-dimensional arrangement of different concentrations of substances and allows the calculation of the FIC, which necessary for assessing the combination's synergism, additivity, indifference or antagonism [59].

To promote greater efficiency of thymol and nystatin when used at lower concentrations, the association of these substances was proposed, and synergistic effect was observed, with reduction of $87.4 \%$ of the concentrations of both products in relation to the effect provided when assessed separately.

There are several mechanisms involved in the synergistic activity of antifungal agents: a) the inhibition of different stages in the fungal intracellular pathways that are essential for cell survival; b) increased penetration of one antifungal agent resulting from the action of another antifungal agent on the fungal cell membrane; c) the inhibition of carrier proteins; and d) the simultaneous inhibition of different cell targets [60]. The mechanism of combined thymol and nystatin appears to involve the inhibition of ergosterol formation as a result of the antifungal agents' action on the different enzymes responsible for the biosynthesis of ergosterol and/or because an increase in cell permeability allows the passage of one or both agents.

It is noteworthy that this is the first study that reports the synergistic effect of combined thymol and nystatin and its potential use to treat superficial infections in the oral mucosa caused by Candida species. Therefore, the findings described here encourage the development of clinical trials to evaluate the efficacy of this combination treatment.

\section{Conclusions}

From the results obtained, it was concluded that thymol has fungicidal action against $C$. albicans, C. tropicalis and $C$. krusei strains, and its effect is probably the result of interference with the synthesis and/or presence of ergosterol in the plasma membrane. The combination of thymol and nystatin had a synergistic effect for inhibiting the growth of these strains.

\section{Abbreviations \\ C. albicans: Candida albicans; C. krusei: Candida krusei; C. tropicalis: Candida tropicalis; CBS: Central Bureau voor Schimmel; CFU: Colony-forming unit; FIC: Fractional inhibitory concentration index; MFC: Minimum fungicidal concentration; MIC: Minimum inhibitory concentration; NUMETROP: Tropical Medicine Center, Center for Health Sciences, Federal University of Paraiba, Paraiba, Brazil; SDA: Sabouraud Dextrose Agar; SDB: Sabouraud Dextrose Broth; TTC (dye): 2,3,5-triphenyl tetrazolium chloride.}

\section{Competing interests}

The authors declare that they have no competing interests.

\section{Authors' contributions}

RDC conceived of the study, and participated in its design and coordination and drafted the manuscript; TMPAS carried out the microbiological tests for determination of MIC, MFC, FIC and synergism; LMDB carried out the microbiological tests for determination of MIC, MFC, FIC and synergism; GLSF participated in microbiological tests for determination of MIC and MFC and helped to draft the manuscript; EMMBC participated in the design of the study and coordination; ALC participated in the design of the study and coordination. All authors read and approved the final manuscript.

\section{Acknowledgement}

The National Counsel of Technological and Scientific Development (CNPq) provided funding. This study was carried out at in the Laboratory of Oral Microbiology, Tropical Medicine Center (NUMETROP) - Center for Health Sciences, Federal University of Paraiba, Paraiba, Brazil. The strains were generously provided by the Microbiology Division, Center for Chemical, Biological and Agricultural research of the State University of Campinas, Piracicaba, Sao Paulo, Brazil.

\section{Author details}

${ }^{1}$ Postgraduate Program in Dentistry, School of Dentistry, Universidade Federal da Paraíba, Campus I, ZIP: 58.051-900 Joao Pessoa, Paraiba, Brazil. ${ }^{2}$ School of Dentistry, Universidade Federal da Paraíba, ZIP: 58.051-900 Joao Pessoa, Paraiba, Brazil. ${ }^{3}$ Post-Graduate Program in Dentistry, State University of Paraiba, Campina Grande, Paraiba, Brazil. 
Received: 28 May 2015 Accepted: 21 November 2015 Published online: 24 November 2015

\section{References}

1. Cornet M, Gaillardin C. pH signaling in human fungal pathogens: a new target for antifungal strategies. Eukaryot Cell. 2014;13:342-52.

2. Alves PM, Leite PHAS, Pereira JV, Pereira LF, Pereira MSV, Higino JS, et al. Antifungal activity of the extract of Psidium guajava Linn. ("goiabeira") upon leavens of Candida of the oral cavity: an in vitro evaluation. Rev Bras Farmacogn. 2006;16:192-6.

3. Mangueira DFB, Mangueira LFB, Diniz MFFM. Candidose oral. R bras ci Saúde. 2010;14:69-72.

4. Monge RA, Román E, Nombela C, Pla J. The MAP Kinase signal transduction network in Candida albicans. Microbiology. 2006;152:905-12.

5. Colombo AL, Nucci M, Park BJ, Nouér SA, Arthington-Skaggs B, da Matta DA, et al. Epidemiology of candidemia in Brazil: a nationwide sentinel surveillance of candidemia in eleven medical centers. J Clin Microbiol. 2006; 44:2816-23.

6. Pfaller M, Neofytos D, Diekema D, Azie N, Meier-Kriesche HU, Quan SP, et al. Epidemiology and outcomes of candidemia in 3648 patients: data from the Prospective Antifungal Therapy (PATH Alliance ${ }^{\circledast}$ ) registry, 2004-2008. Diagn Microbiol Infect Dis. 2012;74:323-31.

7. Dangi YS, Soni ML, Namdeo KP. Oral candidiasis: a review. Int J Pharm Pharm Sci. 2010;2:36-41.

8. Skupien A, Valentini F, Boscato N, Pereira-Cenci T. Prevention and treatment of Candida colonization on denture liners: a systematic review. J Prosthet Dent. 2013;110:356-62.

9. Capistrano HM, Assis EM, Leal RM, Alvarez-Leite ME, Brener S, Bastos EM. Brazilian Green própolis compared to miconazole gel in the treatment of Candida-associated denture stomatitis. Evid Based Complement Alternat Med. 2013;2013:1-6

10. Amin WM, Al-Ali MH, Salim NA, Al-Tarawneh SK. A new form of intraoral delivery of antifungal drugs for the treatment of denture-induced oral candidosis. Eur J Dent. 2009;3:257-66.

11. Khozeimeh F, Shahtalebi MA, Noori M, Savabi O. Comparative evaluation of ketoconazole tablet and topical ketoconazole $2 \%$ in oralbase in treatment of Candida-infected denture stomatitis. J Contemp Dent Pract. 2010;11:17-24.

12. Bondaryk M, Kurzatkowski W, Staniszewska M. Antifungal agents commonly used in the superficial and mucosal candidiasis treatment: mode of action and resistance development. Postępy Dermatol Alergol. 2013;30:293-301.

13. Kamikawa Y, Mori Y, Nagayama T, Fujisaki J, Hirabayashi D, Sakamoto R, et al. Frequency of clinically isolated strains of oral Candida species at Kagoshima University Hospital, Japan, and their susceptibility to antifungal drugs in 2006-2007 and 2012-2013. BMC Oral Health. 2014;14:1-9.

14. Tobudic S, Kratzer C, Presterl E. Azole-resistant Candida spp. - emerging pathogens? Mycoses. 2010;55:24-32.

15. Newman DJ, Cragg GM. Natural products as sources of new drugs over the 30 years from 1981 to 2010. J Nat Prod. 2012;75:311-35.

16. Romero AL, Romero RB, Silva EL, Diniz SPSS, Oliveira RR, Vida JB. Composição química e atividade do óleo essencial de Origanumvulgare sobre fungos fitopatogênicos. UNOPAR Cient Ciênc Biol Saúde. 2012;14:231-35.

17. Ahmad A, Khan A, Akhtar F, Yousuf S, Xess I, Khan LA, et al. Fungicidal activity of thymol and carvacrol by disrupting ergosterol biosynthesis and membrane integrity against Candida. Eur J Clin Microbiol Infect Dis. 2011;30:41-50.

18. Alves LA, Freires IA, Souza TMPA, Lima EO, Castro RD. Effect of Schinus terebinthifolius on Candida albicans growth kinetics, cell wall formation and micromorphology. Acta Odontol Scand. 2013;71(3-4):965-7.

19. Freires IA, Furletti VF, Sartoratto A, Alencar SM, Figueira GM, Murata RM, et al. Coriandrum sativum L. (coriander) essential oil: antifungal activity and mode of action on Candida spp., and molecular targets affected in human whole-genome expression. PloS One. 2014;9:e99086.

20. Bakkali F, Averbeck S, Averbeck D, Idaomar M. Biological effects of essential oils - a review. Food Chem Toxicol. 2008;46:446-75.

21. Edris AE. Pharmaceutical and therapeutic potentials of essential oils and their individual volatile constituents: a review. Phytother Res. 2007;21:308-23.

22. Pauli A. Anticandidal low molecular compounds from higher plants with special reference to compound from essential oils. Med Res Rev. 2006;26:223-68.

23. Pina-Vaz C, Gonçalves Rodriguez A, Pinto E, Costa-de-Oliveira S, Tavares C, Salgueiro $L$, et al. Antifungal activity of thymus oils and their major compounds. J Eur Acad Dermatol Venereol. 2004;18:73-8.
24. Mota KSL, Pereira FO, Oliveira WA, Lima IO, Lima EO. Antifungal activity of Thymus vulgaris L. essential oil and its constituent phytochemicals against Rhizopus oryzae: interaction with ergosterol. Molecules. 2012;17:14418-33.

25. Sánchez MA, Turina AV, García DA, Nolan MV, Perillo MA. Surface activity of thymol: implications for an eventual pharmacological activity. Colloids Surf B Biointerfaces. 2004;34:77-86.

26. Botelho MA, Nogueira NAP, Bastos GM, et al. Antimicrobial activity of the essential oil from Lippia sidoides, carvacrol and thymol against oral pathogens. Braz J Med Biol Res. 2007;40:349-56.

27. Priestley CM, Williamson EM, Wafford KA, Sattelle DB. Thymol, a constituent of thyme essential oil, is a positive allosteric modulator of human GABAA receptors and a homo-oligomeric GABA receptor from Drosophila melanogaster. Br J Pharmacol. 2003;140:1363-72.

28. Sanchez B, Gabriel J, Martinez M, Jairo R, Stashenko E. Actividad antimicobacteriana de terpenos. Rev Univ Ind Santander. 2009;41:231-43.

29. Slamenová D, Horváthová E, Sramková M, Marsálková L. DNA-protective effects of two componentes of essential plant oils carvacrol and thymol on mammalian cells cultured in vitro. Neoplasma. 2007;54:108-12.

30. Archana PR, Rao BN, Ballal M, Rao BSS. Thymol, a naturally occurring monocyclic dietary phenolic compound protects Chineses hamster lung fibroblasts from radiation-induced cytotoxicity. Mutat Res Gen Toxicol Environ Mutagen. 2009;680:70-7.

31. Robledo S, Osorio E, Munoz D, Jaramillo LM, Restrepo A, Arango G, et al. In vitro and in vivo cytotoxicities and antileishmanial activities of thymol and hemisynthetic derivatives. Antimicrob Agents Chemother. 2005;49:1652-5.

32. Clinical and Laboratory Standards Institute (CLSI). Protocol M27-A2. Reference method for broth dilution antifungal susceptibility testing of yeasts. 2nd ed. Pennsylvania: NCCLS; 2002.

33. Deswal DP, Chand U. Standartizationof the tetrazolium test for viability estimation in ricebean (Vigna umbellate T.) seeds. Seed Sci Technol. 1997;25:409-17.

34. Siddiqui ZN, Farooq F, Musthafa TNM, Ahmad A, Khan AU. Synthesis, characterization and antimicrobial evaluation of novel halopyrazole derivatives. J Saudi Chem Soc. 2013;17:237-43.

35. Escalante A, Gattuso M, Pérez P, Zacchino S. Evidence for the mechanism of action of the antifungal phytolaccoside B isolated from Phytolacca tetramera Hauman. J Nat Prod. 2008;71:1720-5.

36. Frost DJ, Brandt KD, Cugier D, Goldman RJ. A whole-cell Candida albicans assay for the detection of inhibitors towards fungal cell wall synthesis and assembly. J Antibiot. 1995;48:306-10.

37. Lima IO, Pereira FO, Oliveira WA, Lima EO, Menezes EA, Cunha FA, et al. Antifungal activity and mode of action of carvacrol against Candida albicans strains. J Essent Oil Res. 2013;25:138-42.

38. Dutta NK, Dastidar SG, Kumar A, Mazumdar K, Ray R, Chakrabarty AN. Antimycobacterial activity of the antiinflammatory agent diclofenac sodium, and its synergism with streptomycin. Braz J Microbiol. 2004;35:316-23.

39. Eliopoulos GM, Moellering RC. Antimicrobial combinations. In: Lorian V, editor. Antibiotics in Laboratory Medicine. 3rd ed. Baltimore: Williams \& Wilkins; 1991. p. 434-41.

40. Nightingale $\mathrm{CH}$, Ambrose PG, Drusano GL, Murakawa T. Antimicrobial Pharmacodynamics in Theory and Clinical Practice. 2nd ed. New York: Informa Helthcare; 2007.

41. Yang ZT, Wu L, Liu XY, Zhou M, Li J, Wu JY, et al. Epidemiology species distribution and outcome of nosocomial Candida spp. Bloodstream infection in Shanghai. BMC Infect Dis. 2014;6:241.

42. Singh A, Verma R, Murari A, Agrawal A. Oral candidiasis: an overview. J Oral Maxillofac Pathol. 2014;18:81-5.

43. Meneses EA, Cavalcante MS, Farias RB, Teixeira AB, Pinheiro FG, Bezerra BP, et al. Frequência e atividade enzimática de Candida albicans isoladas da mucosa bucal de crianças de uma creche da prefeitura de Fortaleza, Ceara. Brasil J Bras Patol Med Lab. 2005;4:9-13.

44. Basso Jr LR, Gast CE, Mao Y, Wong B. Fluconazole transport into Candida albicans secretory vesicles by the membrane proteins Cdr1p, Cdr2p, and Mdr1p. Eukaryot Cell. 2010;9:960-70.

45. Manoharlal R, Gorantala J, Sharma M, Dominique S, Prasad R. PAP1 [poly(A) polymerase 1] homozygosity and hyperadenylation are major determinants of increased mRNA stability of CDR1 in azole-resistant clinical isolates of Candida albicans. Microbiology. 2010;156:313-26.

46. Howell SA, Mallet Al, Noble WC. A comparison of the sterol content of multiple isolates of the Candida albicans Darlington strain with other clinically azole-sensitive and resistant strains. J Appl Microbiol. 1990;69:692-6. 
47. Ellof JN. A sensitive and quick microplate method to determine the minimal inhibitory concentration of plant extracts for bacteria. Planta Med. 1998;64:711-3

48. Bicmen C, Doluca M, Gulat S, Gunduz AT, Tuksavul F. Species level identification and antifungal susceptibility of yeast isolated from various clinical specimens and evaluation of Integral System Yeasts Plus. New Microbiol. 2012;35:327-34.

49. Pozzatti P, Scheid IA, Spader TB, Atayde ML, Santurio JM, Alves SH. In vitro activity of essential oils extracted from plants used as spices against fluconazole-resistant and fluconazole-susceptible Candida spp. Can Microbiol. 2008:54:950-60.

50. Giordani R, Regli P, Kaloustian J, Mikail C, Abou L, Portugal H. Antifungal effect of various essential oils against Candida albicans. Potentiation of antifungal action of amphotericin B by essential oil from Thymus vulgaris. Phytother Res. 2004;18:990-5.

51. Braga PC, Culici M, Alfieri M, Dal SM. Thymol inhibits Candida albicans biofilm formation and mature biofilm. Int J Antimicrob Ag. 2008;31:472-7.

52. Vasconcelos LC, Sampaio FC, Albuquerque AJR, Vasconcelos LCS. Cell viability of Candida albicans against the antifungal activity of thymol. Braz Dent J. 2014:25:277-81.

53. Harris R. Progress with superficial mycoses using essential oils. Int J Aromather. 2002;12:83-91.

54. Coutinho HD, Costa JG, Lima EO, Falcão-Silva VS, Siqueira-Júnior JP. In vitro interference of Hyptis martiusii Benth. \& chlorpromazine against an aminoglycoside-resistant Escherichia coli. Indian J Med Res. 2009;129:566-8.

55. Zago JAA, Ushimaru PI, Barbosa LN, Fernandes JA. Sinergismo entre óleos essenciais e drogas antimicrobianas sobre linhagens de Staphylococcus aureus e Escherichia coli isoladas de casos clínicos humanos. Rev Bras Farmacogn. 2009;19:828-33.

56. Patton $L L$, Bonito AJ, Shugars DA. A systematic review of the effectiveness of antifungal drugs for the prevention and treatment of oropharyngeal candidiasis in HIV-positive patients. Oral Surg Oral Med Oral Pathol Oral Radiol Endod. 2001:92:170-9.

57. Mohamadi J, Motaghi M, Panahi J, Havasian MR, Delpisheh A, Azizian M, et al. Anti-fungal resistance in candida isolated from oral and diaper rash candidiasis in neonates. Bioinformation. 2014;10:667-70.

58. Aleksic V, Mimica-Dukic N, Simin N, Nedeljkovic NS, Knezevic P. Synergistic effect of Myrtus communis L. essential oils and conventional antibiotics against multi-drug resistant Acinetobacter baumannii wound isolates. Phytomedicine. 2014;21:1666-74

59. Odds FC. Synergy, antagonism, and what the chequerboard puts between them. J Antimicrob Chemother. 2003:52:1.

60. Johnson MD, Macdougall C, Ostrosky-Zeichner L, Perfect JR, Rex JH. Combination antifungal therapy. J Antimicrob Chemother. 2004:48:693-715.

\section{Submit your next manuscript to BioMed Central and we will help you at every step:}

- We accept pre-submission inquiries

- Our selector tool helps you to find the most relevant journal

- We provide round the clock customer support

- Convenient online submission

- Thorough peer review

- Inclusion in PubMed and all major indexing services

- Maximum visibility for your research 